\title{
PRINSIP HUKUM PERIMBANGAN DANA BAGI HASIL MINYAK DAN GAS BUMI
}

\author{
Indah Dwi Qurbani \\ indah.qurbani80@ub.ac.id \\ Fakultas Hukum Universitas Brawijaya Malang
}

\begin{abstract}
Based on Article 18 A (2) of the amended 1945 Constitution provisions, it can be inferred that article as the filosophical and constitutional basic of the Act No. 33 of 2004 about finance relationship between central government and regional government, include finance relationship in oil and gas sector. The problem statement in this research are firstly, elaborating of law oil and gas management in Indonesia and secondly analysing the principle of law distribution finance relationship between central government and regional government in sharing oil and gas finance. Social concept of ownership is a fundamental principle in the management of oil and gas as outlined in the basic orientation of national development. Oil and gas sector as a strategic non renewable natural resources shall be under the powers of the State and shall be used to the greatest benefit of the people.
\end{abstract}

Keywords: principles of law, equity, production sharing, oil and gas

\begin{abstract}
Abstrak
Pasal 18 A (2) UUD 1945 menjadi dasar filosofis Undang-Undang Nomor 33 Tahun 2004 tentang hubungan keuangan antara pemerintah pusat dan pemerintah daerah, termasuk hubungan keuangan di sektor minyak dan gas. Pernyataan masalah dalam penelitian ini adalah; (1) Prinsip minyak hukum dan manajemen gas di Indonesia; (2) Prinsip hubungan keuangan distribusi hukum antara pemerintah pusat dan pemerintah daerah dalam berbagi pembiayaan minyak dan gas. Kedaulatan sebagai kekuasaan tertinggi di tangan rakyat termasuk bidang ekonomi. Prinsip hukum dana perimbangan minyak dan gas adalah sistem dana bagi hasil minyak dan gas yang dihasilkan dari daerah daerah dilakukan secara proporsional, demokratis, adil dan transparan dengan memperhatikan keadaan potensi, dan kebutuhan lokal. Prosentase yang proporsional harus, demokratis, adil dan transparan. Minyak dan gas sektor sebagai sumber daya strategis yang tidak terbarukan alami akan berada di bawah kekuasaan negara dan harus digunakan untuk manfaat terbesar dari rakyat.
\end{abstract}

Kata Kunci: prinsip hukum, bagi hasil, minyak dan gas bumi 


\section{Pendahuluan}

Pasal 33 ayat (2) dan ayat (3) Undang-Undang Dasar Negara Republik Indonesia Tahun 1945 (UUD 1945) menegaskan bahwa cabang-cabang produksi yang penting bagi negara dan yang menguasai hajat hidup orang banyak dikuasai oleh negara. Demikian pula bumi, air dan kekayaan alam yang terkandung di dalamnya dikuasai oleh negara dan dipergunakan sebesar-besarnya untuk kemakmuran dan kesejahteraan rakyat. Konsep hak menguasai negara kemudian ditegaskan lebih lanjut dalam Pasal 2 ayat (1) Undang-Undang Nomor 5 Tahun 1960 tentang Peraturan Dasar Pokok-Pokok Agraria (UU No. 5/1960).

Sektor minyak dan gas bumi sebagai salah satu dari sumber daya alam strategis tidak terbarukan yang dikuasai oleh negara serta merupakan komoditas penting yang menguasai hajat hidup orang banyak dan mempunyai peranan penting dalam perekonomian nasional sehingga pengelolaannya harus dapat secara maksimal memberikan kemakmuran dan kesejahteraan rakyat. Negara sebagai organisasi kekuasaan tertinggi bangsa Indonesia memiliki wewenang dan kewajiban untuk melakukan pengelolaan terhadap minyak dan gas bumi. Hal ini selaras dengan 4 (empat) fungsi yang dimiliki negara yaitu:(1). Negara sebagai penjamin (provider);(2). Negara sebagai pengatur (regulator);(3). Negara sebagai pelaku ekonomi (enterpreneur);(4). Negara sebagai pengawas (umpire). Berdasarkan putusan Mahkamah Konstitusi Nomor 36/PUU-X/2012 yang memutuskan bahwa Badan Pengatur Minyak dan gas bumi dinyatakan inkonstitusional. Adalah salah satu hal penting terkait dengan arah pengelolaan minyak dan gas bumi di Indonesia.

Pasal 18 A ayat (2) UUD 1945 mengamanatkan agar hubungan keuangan, pelayanan umum, sumber daya alam dan sumber daya lainnya antara pemerintah pusat dan pemerintahan daerah diatur dan dilaksanakan secara adil dan selaras berdasarkan Undang-Undang. Pasal tersebut merupakan landasan filosofis dan landasan konstitusional pembentukan UndangUndang Nomor 33 Tahun 2004 tentang Perimbangan Keuangan antara Pemerintah Pusat dan Pemerintahan Daerah (UU No. 33/2004), yang di dalamnya juga mengatur perimbangan dana bagi hasil minyak dan gas bumi.

Penerimaan di sektor minyak dan gas bumi sangat bermanfaat bagi pembangunan nasional, termasuk bagi daerah. Karakter industri minyak dan gas bumi yang padat modal, padat resiko dan padat teknologi membuat sektor ini juga bersifat fluktuatif, dipengaruhi oleh kondisi dan harga pasar. Bahkan, tingkat produksi sumber daya alam yang tidak terbarukan ini mengikuti kurva normal, setelah mencapai titik kulminasi dimana akan terjadi winfall profit (pendapatan yang melimpah), suatu saat produksinya-pun akan antiklimaks menuju titik nol. Artinya, pendapatan minyak dan gas bumi yang besar tersebut akan berlangsung dalam waktu yang sangat singkat. Berdasarkan hal tersebut rumusan masalah yang dikaji sekaligus menjadi isu hukum adalah: 1) Prinsip hukum pengelolaan minyak dan gas bumi di Indonesia; 2) Prinsip hukum perimbangan keuangan antara pemerintah pusat dan pemerintahan daerah dalam perimbangan dana bagi hasil minyak dan gas bumi. 


\section{Prinsip Hukum Pengelolaan Minyak dan Gas Bumi di Indonesia}

Banyak bidang yang harus dilindungi oleh negara sebagai bagian dari penguatan internal dan menjaga keuntungan negara serta kesejahteraan rakyat apabila dikaitkan dengan pengelolaan migas salah satunya adalah upaya penyediaan sumber hidup demi kesejahteraan masyarakat sebagai bagian dari kewajiban negara. Hampir semua produk hukum di negaranegara maju sadar akan hal tersebut, salah satu prinsip dasar yang dikeluarkan dalam deklarasi Stockholm tahun 1972.

States have, in accordance with the charter of the united nations and their principles of international law, the sovereign right to exploit their own resources pursuant to their own enviromental policies, and the responsibility to ensure that activities within their jurisdiction or control do not cause damage to the environment of other states or of areas beyond the limit of national jurisdiction. ${ }^{11}$

Prinsip inilah yang kemudian diterjemahkan sebagai prinsip pembangunan berkelanjutan (suistainable development). United Nations General Assembley Resolution on Permanent Sovereignty over Natural Resources yang merupakan prinsip hukum yang terkandung dalam Resolusi Persatuan Bangsa-bangsa secara jelas dan tegas juga mengakui bahwa: 1) Setiap Negara berdaulat atas sumber kekayaan alamnya sendiri; 2) Pembagian keuntungan yang diperoleh dari pengelolaan sumber daya alam tidak boleh merusak kedaulatan suatu negara; 3) Kerja sama internasional untuk pembangunan ekonomi dilaksanakan atas dasar penghormatan terhadap Kedaulatan Negara atas sumber kekayaan alam yang dimilikinya; 4) Hak dan kedaulatan rakyat dan bangsa atas kekayaan alam yang dimilikinya, harus dilaksanakan semata-mata untuk kepentingan pembangunan nasional dan kesejahteraan rakyat dari negara yang bersangkutan.

Restrukturisasi ekonomi, yang ditandai dengan privatisasi dan deregulasi di berbagai sektor ekonomi, termasuk infrastruktur, menjadi gelombang yang dalam dua dekade belakangan telah melanda banyak negara berkembang. Reformasi pasar energi, khususnya di bidang migas, menjadi agenda yang telah dipraktekkan di sejumlah negara berkembang di Asia, Amerika Latin, bahkan Afrika. Restrukturisasi sektor ekonomi pada umumnya dimaksudkan untuk menghasilkan kinerja sistem ekonomi yang lebih efisien, terbuka, adil, menghasilkan manfaat yang lebih besar bagi masyarakat dan lingkungan.

Restrukturisasi sektor energi di Indonesia telah diawali dari berbagai studi pada awal tahun 1990 serta diterapkannya beberapa kebijakan seperti kebijakan restrukturisasi sektor kelistrikan pada tahun 1998 yang berisi sekelompok program untuk meletakkan fondasi yang lebih kokoh bagi pengembangan sektor ketenagalistrikan. Krisis ekonomi atau finansial pada tahun 1997 hingga tahun 1998 telah mempercepat dilahirkannya Undang-undang baru berisi pengaturan ulang sektor energi, yang memberikan dasar bagi perubahan yang lebih fundamental terhadap sektor energi dan pengembangannya di masa depan. Implementasi terhadap hal tersebut untuk menciptakan iklim investasi yang positif di Indonesia, yang juga

1 Principle 21 of Stockholm Declaration, 1972. 
sebagai upaya peneguhan program kebijaksanaan pertumbuhan ekonomi dan industrialisasi sebagai bagian dari konsep developmentalisme terjadi pada tahun 1967, sebagai tindak lanjut dari konferensi Jenewa pada bulan November tahun 1967.

Demokrasi ekonomi Indonesia berdasarkan Pasal 33 UUD 1945 demokrasi ekonomi yang tegas menyatakan kepentingan masyarakat lebih utama dari kepentingan orangseorang. Kemakmuran masyarakat lebih utama dari kemakmuran orang-seorang meskipun kepentingan orang-seorang tetap dihormati. Demokrasi ekonomi mengatakan yang dimaksudkan adalah dari, oleh dan untuk. Sedangkan demokrasi barat biasanya dari dan oleh; untuk Indonesia lebih dari itu, demokrasi ekonomi adalah bahwa cabang-cabang produksi yang penting bagi negara dan menguasai hajat hidup orang banyak dikuasai oleh negara, kalau tidak maka kepentingan rakyat akan terancam dan pemerintah mempunyai kewajiban untuk menjaga kepentingan rakyat, bumi dan air dan kekayaan alam yang terkandung di dalamnya digunakan untuk sebesar-besarnya kemakmuran rakyat.

Dengan volume kontrak yang begitu besar di bidang gas, melalui Undang-Undang Nomor 30 Tahun 2007 Tentang Energi (UU No. 30/2007), dan Peraturan Presiden Nomor 5 Tahun 2006 Tentang Kebijakan Energi Nasional (Perpres No. 5/2006), dan Keputusan Menteri Energi dan Sumber Daya Mineral No. 0983 K/16/MEM/2004 pemerintah mengeluarkan Blueprint Pengelolaan Energi Nasional (BP-PEN) 2005-2025 yang menargetkan tercapai elastisitas energi kurang dari satu dan energi mix primer yang optimal dengan memberikan peranan yang lebih besar terhadap sumber energi alternatif untuk mengurangi ketergantungan pada minyak bumi.

Pada saat harga minyak mentah dunia menembus angka 142 dollar Amerika Serikat per barrel pada bulan Mei tahun 2011, tidak berdampak pada peningkatan income negara disebabkan perpajakan Indonesia belum mengatur secara detail ketentuan peningkatan pendapatan secara tiba-tiba (windfall profit) seperti lonjakan harga minyak dunia. Ketiadaan pengaturan pajak bagi lahan yang dieksplorasi turut memperparah kondisi ini. Negara-negara berkembang seperti Malaysia aturan tadi sejak lama telah dijalankan. Karenanya ke depan pemerintah perlu memperjelas pajak windfall profit dan pajak atas pengalihan ladang minyak (farm -in farm out) serta pajak pengalihan aset (capital gain) bagi perusahaan ekstraksi pertambangan, sekaligus merumuskan beberapa konsep penting seperti; sharing the pain, sharing the risk, dan sharing the success. Selain itu, bagi hasil migas yang semula tampak lebih menguntungkan negara dibanding porsi kontraktor migas, yaitu 70\%:30\% untuk gas hingga 85\%:15\% untuk minyak bumi, namun, bagi hasil itu belum sanggup memberikan keuntungan maksimal bagi rakyat. Sebab, pembagian itu merupakan porsi net income, yang masih harus dipotong dengan biaya operasional, pengeboran dan eksplorasi, yang dikenal dengan dana pengalihan biaya operasi (Cost Recovery). Sedangkan di sisi hilir, hampir semua negara di dunia termasuk negara industri maju kampiun ekonomi pasar bebas, seperti Amerika Serikat, Inggris, Perancis dan Jepang, tidak pernah mempercayakan harga BBM 
dalam negerinya serta security of supply minyaknya pada mekanisme pasar. Negara industri maju tetap saja merasa perlu untuk meletakkan dasar bagi ikut campur tangan pemerintah sebagai acuan pokok dari kebijaksanaan nasionalnya.

Berdasarkan hal tersebut, prinsip hukum pengelolaan migas di Indonesia tertuang dalam Pasal 33 UUD 1945. Pasal 33 UUD 1945 adalah pasal yang dikenal sebagai pasal ideologi dan politik ekonomi Indonesia karena di dalamnya memuat ketentuan tentang hak penguasaan negara atas sumber daya alam yang menguasai hajat hidup orang banyak. Amandemen yang dilakukan pada tahun 2001 terhadap Pasal 33 UUD 1945 memuat dua tambahan pasal dan judul bab, yaitu terletak pada BAB XIV Batang Tubuh Undang-Undang Dasar Negara Republik Indonesia Tahun 1945 dengan judul bab Perekonomian Nasional dan Kesejahteraan Sosial dengan memuat 5 ayat, berikut isinya secara lengkap: (1)Perekonomian disusun sebagai usaha bersama berdasar atas asas kekeluargaan; (2) Cabang-cabang produksi yang penting bagi negara dan menguasai hajat hidup orang banyak dikuasai oleh negara; (3) Bumi, air dan kekayaan alam yang terkandung di dalamnya dikuasai oleh negara dan dipergunakan untuk sebesar-besarnya kemakmuran rakyat; (4) Perekonomian nasional diselenggarakan berdasar atas asas demokrasi ekonomi dengan prinsip kebersamaan, efisiensi berkeadilan, berkelanjutan, berwawasan lingkungan, kemandirian serta dengan menjaga keseimbangan kemajuan dan kesatuan ekonomi nasional; (5) Ketentuan lebih lanjut mengenai pelaksanaan pasal ini diatur dalam undang-undang.

Menurut Sri Edi Swasono, sesungguhnya Pasal 33 UUD 1945 yang asli dengan Pasal 33 UUD 1945 hasil amandemen secara harfiah bisa disimpulkan sama. Namun karena undang-undang sebagai hukum bisa mempunyai interpretasi, apabila interpretasi historisnya dihilangkan dan diganti dengan interpretasi yang lain terutama pada Pasal 33 ayat (4) UUD 1945, maka tentu Pasal 33 UUD 1945 asli bisa berbeda. Namun secara harfiah yang ada sekarang dengan interpretasi yang tidak dipersoalkan itu sama. ${ }^{22}$

Kwik Kian Gie berpendapat, amandemen yang dilakukan terhadap Pasal 33 UUD 1945 tersebut berkaitan dengan liberalisasi di sektor pengelolaan sumber daya alam, hal tersebut sesungguhnya hanyalah justifikasi dari proses liberalisasi yang sudah berlangsung. Arah liberalisasi dalam pengelolaan migas adalah mengecilkan peran negara dalam pengadaan barang dan jasa publik yang merupakan kebutuhan rakyat, pengadaan yang membutuhkan dana besar diserahkan kepada swasta. Namun, karena yang mempunyai modal adalah perusahaan asing maka yang terjadi adalah monopolistik. Rakyat yang sangat membutuhkan terpaksa harus membayar dengan harga tinggi, tidak ada lagi kewajiban negara dalam hal ini pemerintah untuk mengadakan secara gotong royong melalui instrumen pajak. Hal tersebut terjadi karena adanya perubahan orientasi hukum dimana yang berkembang adalah mekanisme pasar sempurna, liberalisasi, swastanisasi dan globalisasi. Bagaimanapun secara

2 Putusan Mahkamah Konstitusi Nomor. 002/PUU-I/2003 Permohonan Pengujian UU No. 22 Tahun 2001 Tentang Minyak dan Gas Bumi terhadap UUD 1945 dimuat dalam berita Negara Republik Indonesia No. 01 Tahun 2005, h. 78. 
perlahan hal ini akan meminggirkan elaborasi gagasan nasionalisme dan patriotisme. ${ }^{33}$ Sedangkan menurut Subianto Tjakrawerdaja, Pengelolaan migas sebagai salah satu sumber perekonomian supaya berdasarkan Pasal 33 Undang-Undang Dasar Negara Republik Indonesia Tahun 1945 harus memuat tujuh ciri konstitusional yaitu: 1) Perekonomian bertujuan untuk mencapai kemakmuran bersama seluruh rakyat, hal ini secara eksplisit dijelaskan dalam penjelasan Pasal 33 UUD NRI Tahun 1945; 2) Keikutsertaan rakyat dalam pemilikan, proses produksi dan menikmati hasilnya. Hal ini sesuai dengan rumusan yang terdapat dalam Pasal 33 ayat (1) dan ayat (4) UUD NRI Tahun 1945; 3) Sesuai dengan prinsip Pasal 33 ayat (4) UUD NRI Tahun 1945 yaitu efisiensi berkeadilan, perekonomian perlu dijalankan dengan menggunakan mekanisme pasar yang berkeadilan yang didasarkan pada persaingan yang sehat dan peranan serta kewenangan negara untuk intervensi jika terjadi kegagalan pasar; 4) peran Negara harus dijamin, sebagaimana diamanatkan Pasal 33 ayat (1) dan ayat (3) UUD NRI Tahun 1945 terutama dalam hal perencanaan ekonomi nasional, dalam membentuk dan menegakkan pelaksanaan Undang-undang, dan dalam hal melaksanakan program pelayanan dan pemberdayaan masyarakat, pembebasan pajak, pemberian subsidi dan lainnya; 5) BUMN sebagai salah satu soko guru kegiatan ekonomi menguasai cabang-cabang produksi yang penting dan yang menguasai hajat hidup orang banyak. Ini jelas tertuang dalam Pasal 33 ayat (2) UUD NRI Tahun 1945; 6) Koperasi sebagai soko guru perekonomian rakyat harus diwujudkan dalam semangat kebersamaan dengan BUMN dan swasta, serta sebagai badan usaha ekonomi rakyat; 7) Perekonomian nasional haruslah merupakan perwujudan dari kemitraan yang sejajar antara koperasi, BUMN dan swasta. Prinsip ini termuat dalam Pasal 33 ayat (1) UUD 1945. ${ }^{44}$

Prinsip hukum yang tertuang dalam Pasal 33 Undang-Undang Dasar Negara Republik Indonesia Tahun 1945 sebagaimana disebut sebagai ciri-ciri konstitusional inilah yang semestinya diterjemahkan dalam seluruh rangkaian peraturan perundang-undangan pengelolaan migas. Terdapat hubungan yang erat antara perencanaan hukum, penyusunan hukum, penegakan hukum dan pendayagunaan hukum yaitu untuk kesejahteraan rakyat, sehingga ada pergeseran paradigma dari teknokratis struktural kearah hukum yang bersifat humanis partisipatoris.

\section{Prinsip Hukum Perimbangan Keuangan Antara Pemerintah Pusat dan Pemerintahan Daerah dalam Perimbangan Dana Bagi Hasil Minyak dan Gas Bumi}

Pada prinsipnya, kebijakan otonomi daerah dilakukan dengan mendesentralisasikan kewenangan-kewenangan yang sebelumnya tersentralisasi di tangan pemerintah pusat. Dalam proses desentralisasi terjadi pergeseran kekuasaan dari pusat ke daerah, jika dalam

3 Kwik Kian Gie, 2008, "Siasat Liberalisasi Ekonomi", Reform Review (Jurnal untuk Kajian dan Pemetaan Krisis), Volume II No. 1 April-Juni 2008, h. 38.

4 Subiakto Tjakrawerdaja, "Menunggu UU Induk Mengenai Perekonomian Nasional”, Reform Review (Jurnal untuk Kajian dan Pemetaan Krisis), Volume II No. 1 April-Juni 2008, h. 40. 
kondisi semula arus kekuasaan pemerintahan bergerak dari daerah ke tingkat pusat, maka diidealkan bahwa sejak diterapkannya kebijakan otonomi daerah tersebut, arus dinamika kekuasaan akan bergerak sebaliknya yaitu dari pusat ke daerah.

Patut dipertimbangkan skema konsepsi holistik dan strategi pembangunan hukum nasional dalam pengelolaan migas dan perimbangan dana bagi hasil migas sebagaimana berikut:

Gambar 1. skema konsepsi holistik dan strategi pembangunan hukum nasional dalam pengelolaan dan perimbangan dana bagi hasil migas

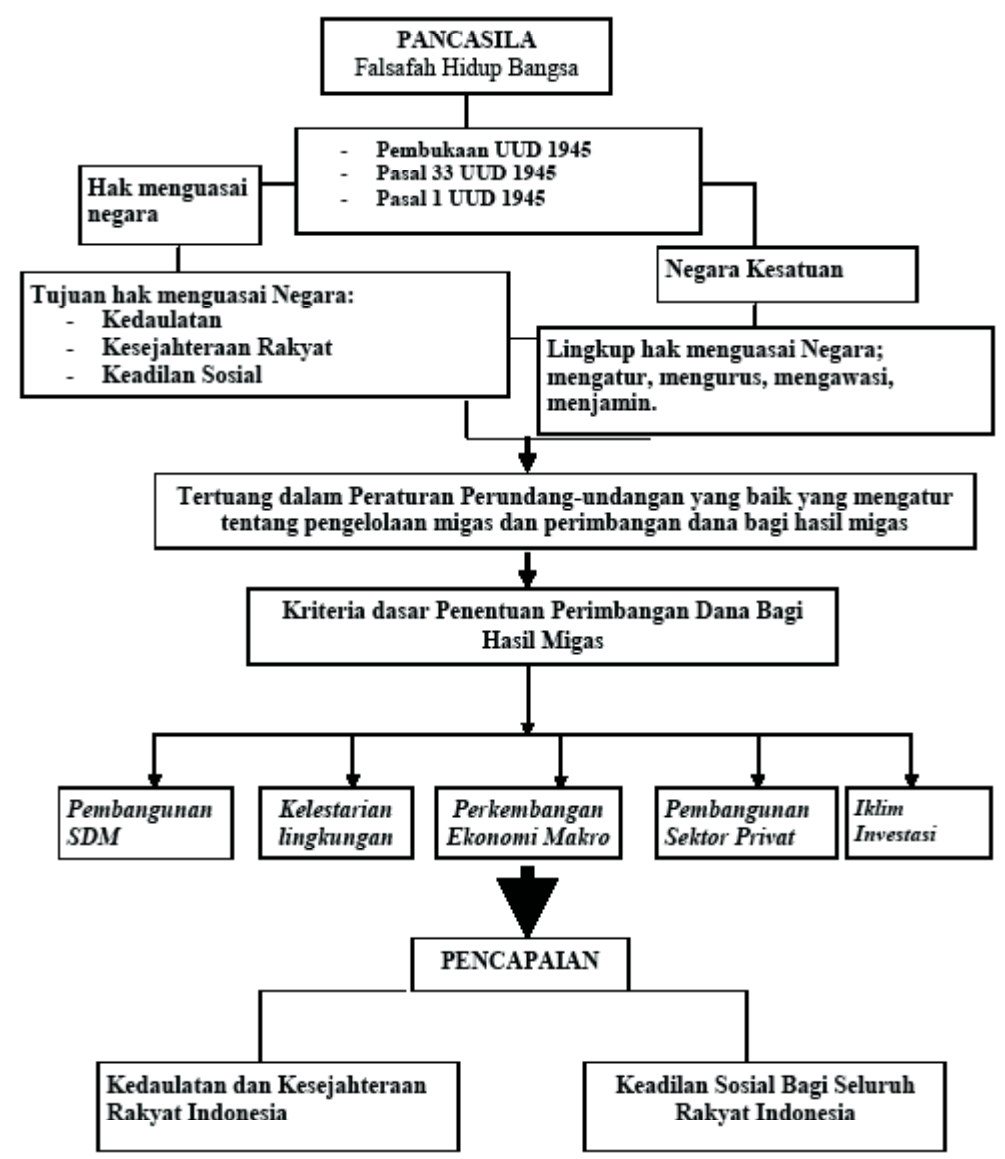

Titik temu dalam skema ini adalah "peraturan perundang-undangan yang baik yang mengatur pengelolaan migas dan perimbangan dana bagi hasil migas", inilah yang dimaksud dengan penerapan prinsip kedaulatan dan keadilan sosial dalam pengelolaan migas dan perimbangan dana bagi hasil migas. Fakta hukum dalam penelitian ini menunjukkan bahwa peraturan perundang-undangan yang mengatur tentang pengelolaan migas dan perimbangan dana bagi hasil migas menuai protes dari sekelompok masyarakat yang keberadaannya terasa tidak terlindungi oleh peraturan perundang-undangan tersebut. Artinya peraturan perundangundangan dimaksud dinilai belum mengakomodasi prinsip keadilan.

Harus dipahami bahwa semua produk hukum merupakan turunan dari Pancasila sebagai kendali filosofis terhadap penyusunan peraturan perundang-undangan. Hal ini tertuang jelas dalam alinea ke-4 Pembukaan UUD NRI Tahun 1945. Pengendalian filosofis 
tersebut tidak hanya berhenti pada konstitusi tetapi mencakup semua perangkat peraturan perundang-undangan mulai dari Undang-Undang, Peraturan Pemerintah, Peraturan Presiden dan hingga peraturan yang paling bawah. Kesemuanya merupakan norma yang menindaklanjuti pasal-pasal dalam konstitusi dan terkontrol oleh lima sila dalam Pancasila sebagai jati diri bangsa, artinya keseluruhan peraturan perundang-undangan dapat kembali atau dikembalikan kepada lima sila tersebut sehingga dapat diterima oleh seluruh bangsa Indonesia.

Keadilan sosial bagi seluruh rakyat Indonesia dalam konteks politik hukum ekonomi Indonesia dimaksud menjadi dasar filosofis kelahiran Pasal 33 UUD 1945. Pasal dimaksud merupakan pasal ideologi dalam demokrasi ekonomi Indonesia. Di dalamnya memuat ketentuan tentang hak menguasai negara atas cabang-cabang produksi yang penting bagi negara dan yang menguasai hajat hidup orang banyak. Dalam hal ini kekuasaan bukan kedaulatan, namun juga bukan tak terbatas. Pembatasan-pembatasan dimaksudkan berupa ketentuan hukum yang mengikat. Sebagaimana Aristoteles ungkapkan ${ }^{55}$ "Hukum yang tidak berkeadilan bukan hukum sebenarnya (an unjust law is not a true law). " Selain itu dalam prespektif filsafat hukum positif sebagaimana dikatakan Jeremy Bentham bahwa hukum harus memberikan kepastian dan menggunakan ukuran-ukuran pasti.

Berdasarkan hal tersebut terdapat kesamaan pemahaman terhadap konsep hak menguasai negara yaitu negara melalui pemerintah memiliki kewenangan menentukan penggunaan, pemanfaatan sumber daya alam untuk kesejahteraan umum dan sebesarbesarnya kemakmuran rakyat. Artinya, hak penguasaan negara dalam Pasal 33 UUD 1945 membenarkan negara untuk mengusahakan sumber daya alam yang berkaitan dengan public utilities dan public services. Sehingga dalam pembentukan peraturan perundang-undangan, Pancasila sebagai falsafah hidup bangsa, tujuan negara dalam pembukaan UUD 1945 dan Pasal 33 UUD 1945 harus mengisi dan berimplikasi pada peraturan perundang-undangan turunannya.

Kekeliruan dalam memaknai prinsip hukum akan berakibat pada substansi hukum itu sendiri yang pada gilirannya dapat menjauhkan keinginan untuk mewujudkan kepastian hukum, transparansi dan kepentingan umum. M. Scheltema mengemukakan bahwa teori hukum yang baik harus memenuhi 4 (empat) unsur yaitu; kepastian hukum, persamaan, demokrasi dan pemerintahan untuk rakyat. Menurut F. Karl Von Savigny bahwa hukum itu lahir dari jiwa rakyat yang mengakomodasi kepentingan jiwa masyarakat (volkgeist).

Konsep holistik strategis sebagai sebuah penerapan prinsip hukum kedaulatan rakyat dan keadilan sosial dalam pengelolaan migas dan perimbangan dana bagi hasil migas adalah sebuah kerangka utuh yang mampu menjawab, menjelaskan, menganalisis dan sekaligus dapat menjadi pedoman logis bagi proses pembentukan peraturan perundang-undangan pengelolaan migas dan perimbangan dana bagi hasil migas. Secara epistemologis konsep

\footnotetext{
5 Taufiq Effendi, Reformasi Birokrasi dan Iklim Investasi, Jakarta: Konstitusi Press, 2013, h. 275.
} 
holistik strategis dimaksudkan memuat arah cara berpikir sistemik, dalam membentuk peraturan perundang-undangan tentang pengelolaan migas dan perimbangan dana bagi hasil migas yang sesuai dengan prinsip hukum tersebut.

Dalam perspektif desentralisasi, walaupun Undang-Undang Nomor 32 Tahun 2004 tentang Pemerintahan Daerah telah mengatur bahwa sejumlah kewenangan pusat diserahkan kepada pemerintahan daerah, fakta hukum berdasarkan pembahasan pada sub bab sebelumnya menunjukkan bahwa dalam pengelolaan migas dan perimbangan dana bagi hasil migas masih ada pemusatan kewenangan, hal ini menunjukkan adanya benturan paradigma antara sentralisasi dan desentralisasi, keadilan menurut penguasa dan keadilan sosial bagi seluruh rakyat Indonesia.

Desentralisasi pemerintahan merupakan sebuah tuntutan yang berkembang di masyarakat merujuk pada pendapat Sir Henry Maine bahwa hukum yang baik adalah mengakomodasi kebutuhan hukum masyarakat, yaitu dapat berupa pemisahan wewenang hingga revisi dan merubah peraturan perundang-undangan yang tidak sesuai dengan kebutuhan hukum masyarakat. ${ }^{66}$ Terkait dengan perimbangan dana bagi hasil migas dan iklim investasi dalam otonomi daerah harus dimaknai bahwa otonomi adalah dalam kerangka Negara kesatuan Republik Indonesia yang didirikan untuk melindungi, mensejahterakan dan mencerdaskan rakyat. Sehingga harus dibangun sistem yang mengakomodir kebutuhan daerah.

Sistem desentralisasi asimetris menurut penulis dapat menjawab persoalan tersebut karena inilah yang disebut sebagai "pengaturan yang adil atau hukum berjalan sesuai dinamika masyarakat." Sebagaimana dikemukakan oleh Van Apeldoorn, ${ }^{77}$ apabila pengaturan tersebut sudah dirasakan membawa keadilan dengan mudah masyarakat akan mendukungnya. Pengaturan yang berkeadilan juga akan menuai suatu harapan bagi masyarakat untuk memperoleh manfaatnya yaitu kesejahteraan. Aspek terpenting berkaitan dengan pengelolaan migas dan perimbangan dana bagi hasil migas adalah kedaulatan dan keadilan. Keadilan adalah "suum cuique tradere" yang diterjemahkan oleh Thomas Aquinas menjadi "the constant and steadfast willingness to give to each person what is his or hers by right (keinginan terus menerus dan tetap untuk memberikan apa yang menjadi haknya)". ${ }^{88}$ Sehingga hukum migas harus mengandung prinsip-prinsip keadilan yaitu: (1) Keadilan bagi pihak-pihak terkait; (2) Undang-Undang Migas mampu memberikan keadilan dalam pengelolaan dan perimbangan dana bagi hasilnya; (3) Undang-Undang Perimbangan yang

6 Harsono, Hukum Tata negara, Pemerintahan Lokal dari Masa Ke Masa, Cetakan Pertama, Yogyakarta, 1992 h. 155.

7 L. Friedman, The Legal System; A Social Science Prespective, New York: Russell Sage Foundation, 1975, h. 49-52.

8 Hal tersebut disampaikan Ulpinus seorang hakim pada Kekaisaran Romawi kemudian diterjemahkan oleh Thomas Aquinas dalam Summa Theologiae, II-II, q. 58, a.1. dikutip Bishop Geoffrey Robinson, 1993, The Challenge of Justice, Canon Law Society of America, Proceedings of the 55 th Annual Convention, Honolulu, October 4-7 1993, h. 1-16. 
mengatur tentang dana bagi hasil antara pemerintah dan pemerintahan daerah harus dapat menjamin masyarakat untuk memperoleh manfaat dan kesejahteraan.

Adapun dalam menjalankan konsep negara kesejahteraan selalu muncul 2 (dua) gejala yaitu: campur tangan pemerintah terhadap aspek kehidupan masyarakat, dan dalam pelaksanaan fungsi pemerintahan sering digunakan asas diskresi yang tidak memiliki kriteria secara jelas. Campur tangan pemerintah berupa pengaturan-pengaturan dimaksudkan untuk menciptakan kesejahteraan masyarakat yang berkeadilan sosial bagi seluruh rakyat Indonesia, artinya gerak kehidupan masyarakat sejalan dengan pembangunan hukum yang dilaksanakan oleh negara. Negara sebagai organisasi kekuasaan tertinggi dari bangsa Indonesia memiliki kewenangan dan kewajiban yang selaras dengan fungsi negara yaitu, negara sebagai penjamin (provider), negara sebagai pengatur (regulator), negara sebagai pelaku ekonomi (enterpreneur), dan negara sebagai pengawas (umpire).

\section{Kesimpulan}

Prinsip Hukum dalam pengelolaan Migas di Indonesia termuat dalam Pancasila sebagai falsafah hidup bangsa yaitu dalam alinea ke-4 Pembukaan UUD 1945 dan Pasal 33 UUD 1945. Hak Menguasai Negara dalam pengelolaan migas harus dimaknai sebagai konsepsi kedaulatan rakyat Indonesia atas segala sumber kekayaan 'bumi, air dan kekayaan alam yang terkandung di dalamnya," sebagai kepemilikan publik oleh kolektivitas rakyat atas sumber-sumber kekayaan, dan kemudian rakyat secara kolektif dikonstruksikan oleh Pasal 33 UUD NRI 1945 memberi mandat kepada negara untuk mengadakan kebijakan (beleid), tindakan pengurusan (bestuursdaad), pengaturan (regelendaad), dan pengelolaan (bestuursdaad). Dalam proses analisis ditemukan secara substansial terdapat inkonsistensi dan ambivalensi dalam Undang-Undang Nomor 22 Tahun 2001 tentang Migas terhadap prinsip hukum pengelolaan Migas tersebut.

Prinsip Hukum perimbangan keuangan antara Pemerintah Pusat dan Pemerintahan Daerah dalam perimbangan dana bagi hasil Migas termuat dalam Pasal 18 A ayat (2) UUD 1945 yang harus dipahami secara komprehensif dengan Pasal 1 UUD 1945. Dinyatakan bahwa hubungan keuangan, pelayanan umum, pemanfaatan sumber daya alam, dan sumber daya lainnya antara Pemerintah Pusat dan Pemerintahan Daerah diatur dan dilaksanakan secara adil dan selaras berdasarkan undang-undang. Perimbangan keuangan antara Pemerintah Pusat dan Pemerintahan Daerah dalam perimbangan dana bagi hasil Migas harus dimaknai sebagai suatu sistem yang menyeluruh dalam rangka pendanaan penyelenggaraan asas desentralisasi, dekonsentrasi dan tugas pembantuan, serta dilaksanakan dalam prinsip negara kesatuan guna pencapaian tujuan negara. Berdasarkan hasil analisis ditemukan bahwa Pasal 14 huruf e dan huruf f, Pasal 19 serta Pasal 20 UU No. 33/2004 hanya mengatur prosentase perimbangan dana bagi hasil migas secara seragam (homogen) tanpa memperhitungkan kondisi Daerah yang bermacam-macam (heterogen). 
Berdasarkan temuan hasil penelitian maka harus segera dilakukan pembentukan Rancangan Undang-Undang tentang Migas yang berlandaskan pada Pasal 33 UUD 1945, berorientasi pada nilai keadilan sosial dan memuat perubahan terhadap tata kelola Migas yang transparan untuk memperkuat peran negara dalam mewujudkan kedaulatan dan mensejahterakan rakyat. Dalam RUU tersebut salah satu materi pokok yang diatur adalah pengembalian status dan fungsi Pertamina sebagai perusahaan Migas nasional (National Oil Company). Untuk mewujudkan kedaulatan dalam pengelolaan Migas, negara berkewajiban melaksanakan pembangunan hukum nasional yang dilakukan secara terencana, terpadu dan berkelanjutan dalam sistem hukum nasional yang menjamin perlindungan hak dan kewajiban segenap rakyat Indonesia berdasarkan UUD 1945, dengan skema konsepsi holistik dan strategi pembangunan hukum nasional dalam pengelolaan dan perimbangan dana bagi hasil migas.

Dilakukan perubahan atas Pasal 14 huruf e dan huruf f, Pasal 19 serta Pasal 20 UU No. 33/2004 bukan prosentase sebagaimana diatur, tetapi dengan penerapan asas desentralisasi asimetris yaitu lebih ditekankan pada strategi dan kebijaksanaan pembangunan yang mendistribusikan dana bagi hasil Migas kepada Pemerintahan Daerah secara proporsional menurut kriteria yang rasional, adil, sesuai kondisi, potensi serta problem khusus di daerah yang bersangkutan dan memberikan keleluasaan ruang gerak (discretionary power) yang lebih besar kepada Pemerintahan Daerah sehingga terwujud kesejahteraan dan keadilan sosial bagi seluruh rakyat Indonesia. Dana bagi hasil dari kegiatan usaha migas harus dilakukan secara transparan, berkeadilan, berwawasan lingkungan, menjamin keamanan, keselamatan, serta kesejahteraan masyarakat.

\section{Daftar Bacaan}

\section{Buku}

Effendi, Taufiq, Reformasi Birokrasi dan Iklim Investasi, Jakarta: Konstitusi Press, 2013.

Friedman, The Legal System: A Social Science Prespective, New York: Russel Sage Foundation, 1975.

Harsono, Boedi, Hukum Agraria Indonesia: Sejarah Pembentukan Undang-Undang Pokok Agraria, Isi dan Pelaksanaannya, edisi revisi, Jakarta: Djambatan, 1999.

\section{Makalah}

Gie, Kwik Kian, "Siasat Liberalisasi Ekonomi" Reform Review (Jurnal untuk Kajian dan Pemetaan Krisis), Volume II No. 1, April-Juni, 2008.

Tjakrawedaja, "Menunggu UU Induk Mengenai Perekonomian Nasional”, Reform Review (Jurnal untuk Kajian dan Pemetaan Krisis), Volume II No. 1, April-Juni, 2008. 